\title{
EFEKTIVITAS PERJANJIAN KERJA ANTARA KARYAWAN DENGAN NOTARIS
}

\author{
Pramadita Anggara Putra \\ Magister Kenotariatan \\ Program Pascasarjana Universitas Islam Malang \\ Jl. Mayjen Haryono No.193 Malang \\ Email : putra.pramaditaanggara@gmail.com
}

\begin{abstract}
Abstrak
Notaris sebagai salah satu profesi dalam menjalankan fungsi dan wewenang nya tentunya banyak berinteraksi dengan banyak orang, tidak hanya internal di lingkungan Kantor Notaris tetapi juga dengan pihak-pihak lain, baik subyek hukum pribadi maupun badan hukum dan atau badan usaha lainnya, ataupun instansi pemerintah. Dalam hubungan tersebut secara internal di kantor notaris, Notaris membutuhkan satu atau lebih Karyawan, tentunya hubungan tersebut tidak hanya sekedar sebuah hubungan, tetapi hubungan yang disebut dengan hubungan hukum. perjanjian kerja yang terjadi antara karyawan dan notaris adalah perjanjian kerja secara lisan, hubungan hukum yang terjadi antara karyawan dan notaris berlangsung dalam jangka waktu yang cukup lama.
\end{abstract}

Kata Kunci: efektivtias, perjanjian kerja, karyawan, notaris

\section{Abstract}

Notary as one of the professions in carrying out their functions and authority certainly interacts with many people, not only internally within the Notary Office but also with other parties, both personal legal and legal entities and or other business entities, or government agencies. Internally, the relationship in the notary's office, a Notary requires one or more Employees, of course the relationship is not just a relationship, but a relationship called legal relationship. work agreements that occur between employees and notaries are verbal work agreements, legal relationships that occur between employees and notaries take place over a period of time. Keywords: effectiveness, work agreement, employee, notary

\section{PENDAHULUAN}

Manusia pada dasarnya tidak bisa melakukan sesuatu secara sendiri, sebagai mahkluk sosial manusia juga perlu berinteraksi dengan manusia yang lain untuk memenuhi kebutuhannya atau untuk mencapai tujuan tertentu. Menurut Aristoteles manusia dikodratkan untuk hidup bermasyarakat dan berinteraksi satu sama lain. Antara manusia atau 
pengemban profesi yang satu dengan manusia lain saling membutuhkan ${ }^{1}$ Manusia dalam memenuhi kebutuhan haruslah bekerja, dalam bekerja kita membutuhkan suatu peristiwa yang mungkin itu melibatkan orang lain agar dapat memberikan hasil berupa uang atau jasa untuk memenuhi kebutuhan sehari-hari.

Notaris sebagai salah satu profesi dalam menjalankan fungsi dan wewenang nya tentunya banyak berinteraksi dengan banyak orang, tidak hanya internal di lingkungan kantor notaris tetapi juga dengan pihak-pihak lain, baik subyek hukum pribadi maupun badan hukum dan atau badan usaha lainnya, ataupun instansi pemerintah.

Dalam hubungan tersebut secara internal di kantor notaris, Notaris membutuhkan satu atau lebih karyawan, tentunya hubungan tersebut tidak hanya sekedar sebuah hubungan, tetapi hubungan yang disebut dengan hubungan hukum,

Hubungan hukum yang terjadi antara karyawan notaris dengan notaris pada dasarnya menimbulkan hak dan kewajiban yang tidak sekedar hubungan antara subyek hukum yang satu dengan yang lain, tetapi juga hubungan hukum yang menimbulkan hak dan kewajiban dalam hal ketenagakerjaan.

Hubungan hukum adalah hubungan antara dua atau lebih subyek hukum. Dalam hubungan hukum ini hak dan kewajiban pihak yang satu berhadapan dengan hak dan kewajiban yang lain ${ }^{2}$. Hubungan hukum yang diatur oleh hukum itu adalah hak dan kewajiban warga, pribadi yang satu terhadap pribadi yang lain, hak dan kewajiban tersebut apabila tidak terpenuhi dapat dikenakan sanksi menurut hukum. Dalam hal hubungan hukum antara notaris dengan karyawan harusnya dituangkan dalam sebuah perjanjian, yang lazimnya disebut sebagai perjanjian kerja, dimana isi dari perjanjian kerja tersebut berisi tentang hak dan kewajiban dari masingmasing pihak. Fakta di lapangan menunjukkan, bahwa hampir sebagian besar perjanjian kerja yang dibuat adalah berbentuk lisan, ketika berbentuk lisan bagaimana ketika salah satu atau kedua belah yang membuat perjanjian kerja tersebut wanprestasi. ${ }^{3}$ Seharusnya perjanjian kerja adalah salah satu pedoman kedua belah pihak baik notaris maupun karyawan dalam menjalankan hak dan kewajibannya masing-masing.

Dalam kenyataan yang terjadi baik notaris maupun karyawan tidak memenuhi baik hak maupun kewajiban masing-masing. meskipun hampir

${ }^{1}$ Abdul Wahid, Mariyadi, dan Sunardi, Penegakan Kode Etik Notaris, (Jakarta: Nirmana Media, 2017), hal 56..

${ }^{2}$ R.Soeroso, Pengantar Ilmu Hukum, (Jakarta: Sinar Grafika, ,2005), hal. 269.

${ }^{3}$ Hasil Wawancara dengan salah satu Karyawan Notaris ( Wawancara dilakukan tanggal 13 Desember 2018 Pukul 14.00 WIB) 
tidak ada kasus perselisihan antara notaris maupun karyawan, pada umumnya karyawan menjadi pihak yang memilih untuk mengakhiri hubungan hukum yang terjadi. Pilihan untuk mengundurkan diri menjadi karyawan notaris menjadi hal yang sudah biasa dilakukan oleh karyawan. Ketika gaji mungkin sudah bertahun tahun tidak mengalami kenaikan, sedangkan secara nyata notaris yang menjadi atasan (pemberi kerja) dalam hal pekerjaan, semakin banyak hal yang harus dikerjakan hal ini menjadi salah faktor kenapa karyawan (penerima kerja) memutuskan untuk keluar dari kantor notaris tersebut. Seharusnya notaris sebagai pemberi kerja juga menerapkan peraturan perundang-undangan di bidang ketenagakerjaan. Sebagai pejabat, seorang notaris idealnya juga menjadi contoh yang baik dalam melaksanakan tanggung jawabnya sebagai seorang pemberi kerja.

Dalam kaitannya dengan notaris, berdasarkan Pasal 40 ayat 1 Undang-Undang Nomor 2 Tahun 2014 tentang Jabatan Notaris digariskan, bahwa setiap akta yang dibacakan oleh notaris dihadiri paling sedikit 2 (dua) orang saksi, kecuali peraturan perundang-undangan menentukan lain. Artinya bahwa dalam menjalankan pekerjaan atau tanggung jawabnya notaris memerlukan bantuan tenaga kerja yang dalam hal ini adalah pekerja/karyawan notaris, sehingga antara notaris dan karyawan notaris terdapat suatu hubungan yang menurut hukum ketenagakerjaan adalah suatu hubungan kerja. Karyawan notaris memegang peranan penting tidak hanya sekedar menjadi saksi dalam setiap akta yang dibuat oleh dan atau dihadapan notaris, tetapi juga membantu notaris menyiapkan akta, melakukan pendaftaran dan pengesahan surat-surat atau akta-akta yang dibuat di bawah tangan. Tanpa karyawan apa yang sudah dipersiapkan akan dilakukan atau dikerjakan notaris tentu tidak akan terlaksana sesuai dengan yang diinginkan. Karena itu keberadaan pekerja atau karyawan harus diperhatikan supaya dapat menjalankan perintah notaris dengan baik.

Hal ini sesuai dengan Pasal 27 ayat (2) Undang-undang Dasar 1945 yang menyatakan bahwa setiap warga negara berhak atas pekerjaan dan penghidupan yang layak bagi kemanusiaan, dan dalam Pasal $28 \mathrm{H}$ ayat (3) menyebutkan, bahwa setiap orang berhak atas jaminan sosial yang memungkinkan pengembangan dirinya secara utuh sebagai manusia yang bermartabat. Hal ini menunjukkan bahwa setiap warga negara mempunyai hak untuk mendapatkan pekerjaan dan berhak atas jaminan sosial. Dalam Pasal 1 angka 4 Undang Undang Nomor 13 Tahun 2003 tentang Ketenagakerjaan, bahwa pengertian pemberi kerja adalah orang perseorangan ,pengusaha, badan hukum, atau badan lainnya yang mempekerjakan tenaga kerja dengan membayar gaji, upah atau imbalan dalam bentuk lainnya. Pasal 1 angka 12 Undang-Undang Nomor 40 Tahun 2004 tentang Sistem Jaminan Sosial Nasional juncto Pasal 1 angka 9 
Undang-Undang Nomor 24 Tahun 2011 tentang Badan Penyelenggara Jaminan Sosial pengertian pemberi kerja adalah orang perseorangan, pengusaha, badan hukum, atau badan lainnya yang mempekerjakan tenaga kerja atau penyelenggara negara yang mempekerjakan pegawai negeri dengan membayar gaji, upah atau imbalan dalam bentuk lainnya. Pekerja adalah setiap orang yang bekerja dengan menerima gaji, upah, atau imbalan dalam bentuk lain. Pengertian Pekerja terdapat dalam Pasal 1 angka 3 Undang-Undang Nomor 13 Tahun 2003 tentang Ketenagakerjaan dan Pasal 1 angka 11 Undang Undang Nomor 40 Tahun 2004 tentang Sistem Jaminan Sosial Nasional juncto Pasal 1.angka 8 Undang-Undang Nomor 24 Tahun 2011 tentang Badan Penyelenggara Jaminan Sosial, bahwa yang dimaksud pekerja adalah setiap orang yang bekerja.

Berdasarkan ketentuan-ketentuan tersebut maka hubungan notaris dengan karyawannya adalah termasuk hubungan kerja antara pemberi kerja dan pekerja, yang menimbulkan adanya hak dan kewajiban diantara pemberi kerja dan pekerja Pasal 1 angka 15 Undang-Undang Nomor 13 Tahun 2003 tentang Ketenagakerjaan (selanjutnya UUK) menyatakan bahwa hubungan kerja antara pengusaha dengan pekerja dibuat berdasarkan perjanjian kerja, yang mempunyai unsur pekerjaan, upah dan perintah. Secara sosiologis, pekerja atau karyawan memang merupakan pihak yang lebih lemah dibanding pihak pemberi kerja. pekerja atau karyawan adalah orang yang tidak bebas dalam menentukan kehendaknya terhadap pemberi kerja, karena dalam suatu hubungan kerja pemberi kerja telah memberikan batasanbatasan yang harus diikuti oleh pihak pekerja atau karyawan. ${ }^{4}$ Hubungan kerja merupakan hubungan antara pemberi kerja dengan penerima kerja yang mempunyai unsur-unsur seperti pekerjaan, upah dan Perintah, karena unsur-unsur tersebut terpenuhi, Notaris harusnya juga tunduk pada UUK, namun dalam kenyataannya masih banyak notaris sebagai pemberi kerja tidak memenuhi kewajiban sesuai dengan UUK.

\section{METODE PENELITIAN}

Dalam penelitian ini jenis yang digunakan adalah penelitian yuridis empiris yang dengan kata lain adalah jenis penelitian hukum sosiologis dan dapat disebut pula dengan penelitian lapangan, yaitu mengkaji ketentuan hukum yang berlaku serta apa yang terjadi dalam kenyataannya di masyarakat, ${ }^{5}$ atau dengan kata lain yaitu suatu penelitian yang dilakukan terhadap keadaan sebenarnya atau keadaan nyata yang terjadi di masyarakat

\footnotetext{
2015 .

${ }^{4}$ Peraturan Pemerintah Republik Indonesia tentang Pengupahan nomor 78 tahun

${ }^{5}$ Bambang Waluyo, Penelitian Hukum dalam Praktek, (Jakarta, Sinar Grafika,2002), hal.15.
} 
dengan maksud untuk mengetahui dan menemukan fakta-fakta dan data yang dibutuhkan, setelah data yang dibutuhkan terkumpul kemudian menuju kepada identifikasi masalah yang pada akhirnya menuju pada penyelesaian masalah. Jenis penelitian ini dipilih agar dalam penelitian yang dilakukan bisa secara efektif menunjukkan antara bagaimana kenyataan dari permasalahan yang ada dengan bagaimana yang seharusnya menurut peraturan perundang-undangan, sehingga antara kenyataan dengan aturan, sudah sesuai atau kah masih jauh dari kesesuaian diantara keduanya.

Pendekatan yang digunakan dalam penelitian adalah pendekatan yuridis sosiologis. Pendekatan yuridis sosiologis adalah mengidentifikasi dan mengkonsepsikan hukum sebagai institusi sosial yang sosiologis dan fungsional dalam sistem kehidupan nyata. ${ }^{6}$

Pendekatan ini menekankan penelitian yang bertujuan untuk memperoleh pengetahuan hukum secara yuridis sosiologis artinya perjanjian kerja yang sudah dibuat oleh para pihak baik tertulis maupun tidak tertulis sudah dianggap sebagai suatu harapan (das sollen ) apakah sudah sesuai dengan kenyataannya (das sein). Bagaimana sebenarnya sebuah perjanjian kerja mengikat para pihak dan bagaimana jika salah satu pihak atau kedua belah pihak melakukan wanprestasi. Hal ini bisa dikaji .Dengan cara melakukan wawancara terhadap beberapa karyawan notaris dan atau notaris yang ada di Kota Malang.

Selain itu pendekatan secara perundang-undangan (statue approach) dilakukan dengan memahami semua peraturan perundang-undangan yang berhubungan dengan masalah penelitian yang akan diteliti, yaitu terhadap peraturan perundang-undangan yang mengatur tentang perjanjian dan ketenagakerjaan.

\section{PEMBAHASAN}

Notaris adalah pejabat yang diangkat oleh Pemerintah yang memperoleh kewenangan secara atributif dari Negara. Notaris bertindak untuk melayani kebutuhan masyarakat dalam hubungan hukum. Dalam pelayanannya notaris terikat pada peraturan jabatan dan kode etik profesi sebagai notaris. Dengan adanya kode etik dan peraturan jabatan, maka notaris terikat dalam satu peraturan yang memuat kaidah moral dan sanksi-sanksi yang akan diberikan bila Notaris melakukan pelanggaran. Di dalam konsideransi huruf c Undang-Undang Jabatan Notaris Nomor 2 Tahun 2014 Tentang Jabatan Notaris, disebutkan bahwa Notaris merupakan jabatan tertentu yang menjalankan profesi dalam pelayanan hukum kepada masyarakat. Notaris merupakan

${ }^{6}$ Soerjono Soekanto, Pengantar Penelitian Hukum, (Jakarta; Universitas Indonesia Press, 1986), hal.51. 
pemberi kerja, menurut Pasal 1 angka 4 UUK, pemberi kerja adalah orang perseorangan, pengusaha, badan hukum, atau badan-badan lainnya yang mempekerjakan tenaga kerja dengan membayar upah atau imbalan dalam bentuk lain. Sebagai orang perseorangan, notaris juga memerlukan pekerja sebagai penunjang profesional kerjanya. Tanpa pekerja, notaris tidak dapat melaksanakan profesinya dengan cepat atau tepat waktu. Notaris selalu menitikberatkan pencarian pekerja yang utama hanya sebatas lulus pendidikan Sekolah Menegah Atas (SMA), bagi notaris lulusan SMA akan lebih mempunyai semangat kerja yang tinggi sehingga dapat diberikan gaji atau upah yang rendah dibandingkan pekerja lulusan sarjana. Pekerja notaris memiliki potensi yang besar untuk menjalankan aktivitas notaris. Notaris dan pekerja merupakan dua hal yang saling membutuhkan. Bagi pekerja, keberhasilan merupakan aktualisasi potensi diri sekaligus peluang untuk memenuhi kebutuhan hidupnya sedangkan bagi notaris, keberhasilan merupakan sarana menuju pertumbuhan dan perkembangan kesuksesan notaris. Sehingga kemampuan dan keterampilan serta keahlian karyawan notaris perlu terus menerus ditingkatkan, baik melalui perencanaan maupun program pelatihan dan pemagangan yang lebih luas agar mampu dalam membantu kerja notaris secara optimal.

Dalam dunia pekerjaan antara pemberi kerja di sini, adalah notaris dengan karyawan nya, di sini adalah karyawan notaris yang diawali dengan adanya hubungan hukum. Hubungan hukum adalah hubungan antara subjek hukum ataupun antara subjek hukum dengan objek hukum, yang diatur oleh hukum dan menimbulkan akibat hukum yaitu hak dan kewajiban.Setiap hubungan hukum yang diciptakan oleh hukum selalu mempunyai dua sisi. Sisi yang satu ialah hak dan sisi lainnya adalah kewajiban, karena pada hakikatnya sesuatu pasti ada pasangannya, tidak ada hak tanpa kewajiban atau sebaliknya. Menyalahgunakan hak dianggap ada, apabila orang menjalankan haknya tidak sesuai dengan tujuan. Ada prestasi yang harus dilaksanakan oleh kedua belah pihak ini. Pemenuhan segala prestasi ini yang akan menimbulkan keharmonisan ataupun disharmonisasi dalam hubungan kerja. Hubungan hukum antara notaris sebagai pemberi kerja dengan pekerja merupakan hubungan kerja. Secara garis besar hubungan kerja yaitu hubungan yang meliputi hak dan kewajiban antara pekerja dan pemberi kerja, terjadi setelah diadakan perjanjian oleh pekerja dengan pemberi kerja (perjanjian kerja).

Menurut Pasal 1 angka 14 UUK, perjanjian kerja adalah perjanjian antara pekerja/buruh dengan pengusaha atau pemberi kerja yang memuat syarat-syarat kerja, hak dan kewajiban para pihak. Terjalinnya hubungan kerja antara Notaris/PPAT dan pekerjanya 
seharusnya dimulai dengan perjanjian kerja. Sehingga syarat-syarat kerja, hak dan kewajiban para pihak jelas. Jika terjadi pelanggaran mengenai hal yang telah diperjanjikan maka sudah ada yang mengikat para pihak untuk bertanggung jawab. Hubungan kerja merupakan hubungan saling ketergantungan antara pengusaha dan pekerja. Secara yuridis, Pasal 1 angka 15 UUK merumuskan hubungan kerja adalah hubungan antara pemberi kerja dengan pekerja/buruh berdasarkan perjanjian kerja, yang mengandung adanya unsur pekerjaan, upah, dan perintah. Unsur pekerjaan adalah objek perjanjian sehingga menjadi faktor paling utama timbulnya perjanjian kerja. Oleh karena itu, jika perkerjaan yang dijanjikan tidak ada, dapat dikatakan perjanjian kerja tersebut batal demi hukum. Unsur upah adalah hak pekerja yang diterima dan dinyatakan dalam bentuk uang atas suatu pekerjaan dan atau jasa yang telah atau akan dilakukan, sedangkan unsur perintah adalah hak pemberi kerja/pengusaha dan merupakan kewajiban pekerja untuk melaksanakan pekerjaan seperti yang diinginkan pengusaha, dan merupakan bagian akhir dari unsurunsur hubungan kerja setelah adanya pekerjaan dan adanya upah.

Notaris dapat diartikan sebagai pihak pemberi kerja. Pemberi kerja dalam menjalankan usaha sangat tergantung dan membutuhkan pekerja agar usahanya dapat berjalan dengan baik dan mendatangkan keuntungan. Pada sisi lain, menurut Zainal Asikin pekerja dalam kehidupannya tentu menginginkan kesejahteraan dan memiliki kebutuhan yang beraneka ragam, untuk dapat memenuhi semua kebutuhan tersebut pekerja dituntut untuk bekerja. Pemberi kerja berhak menuntut prestasi dari pekerjanya berupa pekerjaan tertentu atas perintahnya dan sebaliknya pekerja berkewajiban memenuhi tuntutan itu dengan hak untuk menuntut upah tertentu dari pihak pemberi kerja.Setiap pekerja baik itu Pegawai Negeri Sipil, karyawan swasta, buruh ataupun pekerja kantor notaris punya hak yang sama dimata hukum, yaitu hak untuk mendapatkan perlindungan di dalam mereka bekerja. Perlindungan hukum adalah suatu perlindungan yang diberikan terhadap subyek hukum dalam bentuk perangkat hukum baik yang bersifat preventif maupun yang bersifat represif, baik yang tertulis maupun tidak tertulis. Dengan kata lain perlindungan hukum sebagai suatu gambaran dari fungsi hukum, yaitu konsep dimana hukum dapat memberikan suatu keadilan, ketertiban, kepastian, kemanfaatan dan kedamaian.

Kata perlindungan hukum menunjukkan arti bahwa hukum itu melindungi sesuatu. Sesuatu yang dilindungi oleh hukum adalah kepentingan manusia, karena memang hukum itu dibuat oleh dan untuk manusia atau masyarakat. Berangkat dari pemahaman ini, Perjanjian kerja dapat memberikan perlindungan hukum baik kepada karyawan dan 
notaris, hal ini kareana kata perlindungan hukum sebenarnya erat kaitannya dengan fungsi hukum dan tujuan hukum. Mengenai apa fungsi hukum pada umumnya ahli hukum sudah sepakat mengatakan bahwa fungsi hukum merupakan perlindungan kepentingan manusia. Perlindungan hukum terhadap pekerja merupakan pemenuhan hak dasar yang melekat dan dilindungi oleh konstitusi sebagaimana yang diatur di dalam Pasal 27 ayat (2) dan Pasal 28D Undang-Undang Dasar Negara Republik Indonesia Tahun 1945 (selanjutnya dibaca UUD 1945) yaitu tiap-tiap warga negara berhak atas pekerjaan dan penghidupan yang layak bagi kemanusiaan dan setiap orang berhak atas pengakuan, jaminan, perlindungan dan kepastian hukum yang adil serta perlakuan yang sama dihadapan hukum. Pelanggaran terhadap hak dasar yang dilindungi konstitusi merupakan pelanggaran hak asasi manusia.

Perlindungan terhadap tenaga kerja dimaksudkan untuk menjamin hak-hak dasar pekerja dan menjamin kesamaan serta perlakuan tanpa diskriminasi atas dasar apapun untuk mewujudkan kesejahteraan pekerja dan keluarganya dengan tetap memperhatikan perkembangan kemajuan dunia usaha dan kepentingan pengusaha. Perlindungan hukum bagi pekerja menurut UUK meliputi perlindungan waktu kerja, keselamatan dan kesehatan kerja, pengupahan dan kesejahteraan. Perlindungan waktu kerja meliputi lama bekerja sehari atau seminggu, waktu istirahat dan cuti, perlindungan keselamatan dan kesehatan kerja meliputi pengawasan keselamatan dan kesehatan mental dan fisik, perlindungan kesejahteraan meliputi jaminan sosial, dan perlindungan pengupahan meliputi kelayakan upah. Para pencari kerja tergiur untuk bekerja di kantor-kantor notaris dengan harapan upah atau gaji yang besar. Menurut Pasal 1 angka 30 UUK menyebutkan bahwa upah adalah hak pekerja/buruh yang diterima dan dinyatakan dalam bentuk uang sebagai imbalan dari pengusaha atau pemberi kerja kepada pekerja/buruh yang ditetapkan dan dibayarkan menurut suatu perjanjian kerja, kesepakatan, atau peraturan perundang-undangan, termasuk tunjangan bagi pekerja/buruh dan keluarganya atas suatu pekerjaan dan/atau jasa yang telah atau akan dilakukan.

Perlindungan upah merupakan salah satu aspek yang paling penting, didalam Pasal 88 ayat (1) UUK bahwa setiap pekerja/buruh berhak memperoleh penghasilan untuk penghidupan yang layak. Penghidupan yang layak, yaitu dimana pendapatan pekerja/buruh dari hasil pekerjaannya mampu memenuhi kebutuhan hidup pekerja/buruh dan keluarga secara wajar yang meliputi makanan, minuman, sandang, perumahan, pendidikan, kesehatan, rekreasi dan jaminan hari tua. Upah 
atau gaji merupakan salah satu hak dasar pekerja/buruh yang bersifat sensitif, karena tidak jarang dapat menimbulkan perselisihan.

Beberapa pekerja Notaris/PPAT, menyebutkan bahwa selama bekerja di kantor Notaris/PPAT mereka ada yang terikat dan tidak terikat dengan perjanjian kerja. Mereka yang tidak terikat perjanjian kerja memiliki posisi yang lemah, yang mengakibatkan tidak ada keseimbangan antara hak-hak pekerja kantor Notaris/PPAT dengan kewajiban-kewajiban yang telah dilaksanakannya. Selain mengenai perjanjian kerja mereka belum mendapatkan perlindungan kerja terutama perlindungan upah yang sesuai dengan ketentuan peraturan perundangundangan. Hal yang lebih menyedihkan pekerja Notaris/PPAT diberikan upah dibawah standar upah minimum bahkan terkadang jauh dibawah batas kewajaran upah perbulannya.

Mereka juga menyebutkan, Notaris/PPAT terkadang meminta mereka untuk lembur tapi tidak diberikannya upah lembur. Pada dasarnya kerja lembur bersifat kesukarelaan, tidak boleh ada paksaan, tetapi hal tersebut bisa terjadi karena ada kesepakatan antara pekerja dengan atasan. Jika pekerja menolak untuk lembur maka tidak dapat dipaksakan untuk melakukan lembur. Upah lembur mereka hanya diganti dengan makanan tanpa kesepakatannya dengan pekerjanya. Namun, jika pekerja libur seperti sakit dan terkena musibah, langsung dipotong upah mereka tanpa memperdulikan alasan mereka libur.

Kehidupan dan pekerjaan adalah dua sisi dari satu mata uang, agar orang dapat hidup maka orang harus bekerja. Di dalam UUK menyebutkan tentang perlindungan tenaga kerja, menjamin kesamaan kesempatan serta perlakukan tanpa diskriminasi serta mewujudkan kesejahteraan pekerja dan keluarganya. Hal serupa juga terdapat dalam UUD 1945 dalam Pasal 27 ayat (2) menjamin atas pekerjaan dan penghidupan yang layak bagi kemanusian.

Tenaga kerja menurut UUK diatas sejalan dengan pengertian tenaga kerja pada umumnya, bahwa pengertian tenaga kerja adalah mencakup penduduk yang sudah atau sedang bekerja, yang sedang mencari kerja dan yang melakukan pekerjaan lain seperti sekolah dan mengurus rumah tangga.

Permasalahan yang timbul dalam hubungan antara karyawan dan notaris tidaklah terbatas pada hubungan di dalam internal kantor saja, banyak hal yang penulis temui dan temukan dalam lingkungan kerja notaris dan karyawan, baik konflik di dalam maupun di luar kantor, sebagai sebuah hubungan hukum yang menimbulkan hak dan kewajiban di antara karyawan dan notaris hendaknya para pihak saling memahami bahwa satu dengan 
yang lain sama sama membutuhkan, sehingga jika pemikiran sudah saling sepaham, maka hubungan hukum dalam pekerjaan berlangsung harmonis,

Hasil penelitian yang penulis ke beberapa karyawan/notaris bisa penulis pahami sebagai berikut :

1. Hubungan kerja antara karyawan dan notaris hanya berbentuk perjanjian kerja secara lisan

2. Dalam penerimaan karyawan dikenal masa percobaan.

3. Hubungan kerja yang terjadi bisa bertahun-tahun tanpa kejelasan status

4. Upah yang diberikan kurang dari UMK Kota Malang (untuk Notaris yang SK penetapan notarisnya dibawah 5 tahun )

5. Karyawan tidak diikutsertakan dalam program BPJS Kesehatan maupun Ketenagakerjaan.

6. Berakhirnya hubungan kerja tidak secara tegas ditentukan.

7. Dalam hal terjadi wanprestasi karena perjanjian kerjanya tidak secara tertulis maka sulit ditentukan bagaimana jika terjadi wanprestasi yang dilakukan salah satu satu atau kedua belah pihak.

Sebagai negara yang merdeka dan berdaulat, Indonesia mempunyai tujuan negara sebagaimana tersurat dalam alinea keempat PembukaanpUndang-undang Dasar 1945 yang menyebutkan bahwa tujuan negara antara lain melindungi segenap bangsa dan seluruh tanah tumpah da rah Indonesia, memajukan kesejahteraan umum mencerdaskan kehidupan bangsa serta melaksanakan perdamaian dunia. Tujuan negara tersebut dapat tercapai melalui pembangunan nasional. Pembangunan nasional sebagai amanat Pembukaan UUD 1945 pada hakikatnya bertujuan untuk mewujudkan masyarakat yang adil, makmur dan sejahtera. Pembangunan nasional dilaksanakan antara lain melalui pembangunan dibidang ekonomi. Pembangunan nasional khususnya dibidang perekonomian tidak terlepas dari pembangunan ketenagakerjaan. Pembangunan ketenagakerjaan mempunyai arti penting bagi pencapaian kemakmuran dan kesejahteraan masyarakat secara materil, oleh sebab itu pembangunan ketenagakerjaan dengan sarana hukum ketenagakerjaan mempunyai karakteristik khusus dalam hubungan pengusaha dan pekerja serta pemerintah. Karakteristik tersebut berupa penghapusan sub ordinasi antara pemberi kerja dan pekerja (karyawan). Hubungan ketenagakerjaan yang terjadi adalah keseimbangan dan kesetaraan antara pekerja dan pengusaha.

Dari hubungan hukum tersebut timbullah tanggung jawab notaris terhadap pemenuhan hak-hak karyawan, dari penelitian yang penulis lakukan ternyata ditemukan fakta-fakta sebagai berikut:

1. Bahwa upah/gaji yang diterima oleh karyawan pada notaris yang mempunyai SK dibawah 5 tahun, masih dibawah UMK Kota 
Malang, sedangkan bagi Karyawan yang bekerja pada notaris yang mempunyai SK diatas 5 Tahun sudah diatas UMK Kota Malang.

2. Bahwa karyawan baik yang bekerja di notaris yang SK Pengangkatannya dibawah 5 tahun atau diatas 5 tahun, sama-sama tidak diikut sertakan dalam program jaminan sosial baik ketenagakerjaan maupun kesehatan.

3. Dalam menjalankan kewajibannya karyawan notaris tidak diberikan upah lembur jika melakukan lembur. Dalam kenyataannya seringkali karyawan pulang kerja melebihi jam kerja yang sudah disepakati.

Akibat hukum jika salah satu/kedua belah pihak wanprestasi (karyawan dan atau notaris). Notaris sebagai pemberi kerja tentu nya tidak terlepas dari kewajiban. Kewajiban ialah suatu beban yang bersifat kontraktual. Hak dan Kewajiban timbul apabila terjadi hubungan hukum antara dua pihak yang didasarkan pada suatu kontrak atau perjanjian, jadi selama hubungan hukum yang lahir dari perjanjian itu belum berakhir, maka pada salah satu pihak ada beban kontraktual, ada keharusan atau kewajiban untuk memenuhinya. Sebaliknya apa yang dinamakan tanggung jawab adalah beban yang bersifat moral. Pada dasarnya sejak lahirnya kewajiban sudah lahir pula tanggung jawab. ${ }^{7}$ Begitu juga karyawan juga mempunyai kewajiban sesuai dengan tanggung jawabnya, bagaimana jika karyawan dan atau notaris melakukan sebuah wanprestasi.

Dalam hubungan kerja antara karyawan dan notaris, bentuk bentuk wanprestasi yang dilakukan antara lain :

1. Karyawan tidak mampu menyelesaikan sebuah akta yang diminta oleh notaris dalam jangka waktu yang sudah ditentukan, misalnya notaris akan membuat sebuah akta perjanjian jual beli pada hari Kamis tanggal 13 Desember 2018, perintah untuk membuat akta dari notaris ke karyawan pada hari Jum'at tanggal 7 Desember 2018, akan tetapi pada hari akan ditanda tangani nya akta perjanjian jual beli tersebut, karyawan belum mampu menyelesaikannya, hal ini menyebabkan notaris di mata klien tidak profesional.

2. Karyawan diperintahkan oleh notaris untuk membayar pajak daerah pada hari Rabu 12 Desember 2018, akan tetapi sampai 1 Minggu, pajak tersebut belum dibayarkan, dan baru dibayarkan pada hari rabu 26 Desember 2018. hal ini bisa memperlambat pekerjaan yang dilakukan oleh notaris. Artinya Karyawan memenuhi kewajibannya tapi terlambat.

3. Notaris sebagai pemberi kerja terkadang memberikan upah kepada karyawan nya terlambat memenuhinya.

${ }^{7}$ Soedikno Mertokusumo, Mengenal Hukum suatu Pengantar, (Yogyakarta: Liberty, 2010), hlm.49 
4. Notaris tidak memberikan upah sesuai dengan yang sudah diperjanjikan.

Terdapat fakta bahwa jika yang melakukan wanprestasi adalah karyawan bisa terjadi karyawan tersebut diminta untuk mengundurkan diri dari kantor notaris tersebut, lain hal nya jika yang melakukan wanprestasi adalah notaris, maka karyawan hanya bisa bersikap pasitf, tidak bisa berbuat apa apa, hal ini dikarenakan posisi karyawan lebih rendah daripada notaris.

Pada dasarnya, perjanjian kerja tidak harus dilakukan secara tertulis. Berdasarkan Pasal 50 jo. Pasal 51 UUK, hubungan kerja terjadi karena adanya perjanjian kerja antara pengusaha dan pekerja/buruh, yang mana perjanjian kerja dapat dibuat secara tertulis atau lisan. Akan tetapi, terdapat pengecualian dalam hal perjanjian kerja untuk waktu tertentu ("PKWT"). Dalam Pasal 57 UUK ditegaskan bahwa PKWT harus dibuat secara tertulis serta harus menggunakan bahasa Indonesia dan huruf latin. PKWT yang dibuat tidak tertulis dinyatakan sebagai perjanjian kerja untuk waktu tidak tertentu ("PKWTT").

Menurut Pasal 1338 KUH Perdata, perjanjian yang dibuat secara sah tersebut berlaku sebagai Undang-undang bagi para pihak yang membuatnya, dari hasil penelitian yang penulis lakukan ternyata bahwa perjanjian kerja yang dilakukan antara notaris dan karyawan dibuat secara lisan, dalam hukum ketenagakerjaan memang dikenal ada nya Perjanjian Kerja yang dibuat secara lisan, hal ini sesuai dengan Pasal 1 angka 14 UUK bahwa perjanjian kerja adalah perjanjian antara pekerja dan pengusaha secara lisan dan/atau tertulis, baik untuk waktu tertentu atau untuk waktu tidak tertentu yang memuat syarat-syarat kerja, hak dan kewajiban para pihak", akan tetapi apakah hubungan kerja antara notaris dan karyawan termasuk dalam hubungan yang bisa diperjanjikan secara lisan,

Menurut UUK, bahwa jika perjanjian kerja untuk waktu tidak tertentu maka bisa diperjanjikan secara lisan, jika perjanjian kerja untuk waktu tertentu haruslah dibuat secara tertulis, Hubungan kerja antara karyawan dan notaris bersifat terus menerus dan tetap, sehingga perjanjian kerja bisa dibuat secara lisan, akan tetapi perjanjian lisan juga memiliki banyak kekurangan, Perjanjian kerja bisa berbentuk lisan dan tertulis. Dalam hal perjanjian kerja dibuat secara lisan, perjanjian tersebut tetap mengikat kedua belah pihak (pekerja dan pemberi kerja). Namun kelemahan dari perjanjian kerja secara lisan adalah jika salah satu pihak tidak memenuhi kewajiban sesuai dengan yang telah diperjanjikan dan terjadi perselisihan, akan sulit mencapai penyelesaian. Karena perjanjian yang dibuat secara tidak tertulis sehingga sulit untuk dibuktikan mengenai hal-hal apa saja yang telah diperjanjikan sebelumnya. Sementara perjanjian kerja 
yang dibuat secara tertulis dapat dijadikan alat jika salah satu pihak tidak memenuhi apa yang telah diperjanjikan.

Perjanjian kerja yang dibuat secara tertulis sekurang-kurangnya harus memuat :

1. Nama, alamat perusahaan, dan jenis usaha

2. Nama, jenis kelamin, umur, dan alamat pekerja/buruh

3. Jabatan atau jenis pekerjaan

4. Tempat pekerjaan

5. Besarnya upah dan cara pembayarannya

6. Syarat syarat kerja yang memuat hak dan kewajiban pengusaha dan pekerja/buruh

7. Mulai dan jangka waktu berlakunya perjanjian kerja

8. Tempat dan tanggal perjanjian kerja dibuat; dan. tanda tangan para pihak dalam perjanjian kerja.

Perjanjian kerja baik tertulis maupun lisan efektvitas nya dapat dinilai dari beberapa hal. Hukum yang efektif adalah jika tujuan keberadaan dan penerapannya dapat mencegah perbuatan-perbuatan yang tidak diinginkan dan dapat menghilangkan kekacauan, Perjanjian kerja sebenarnya adalah salah satu pedoman bagi karyawan maupun notaris dalam menjalankan hak dan kewajiban masing-masing, jika berbentuk tertulis maka lebih mudah bagi para pihak untuk melihat hak dan kewajiban nya masing-masing, jika perjanjian kerja berbentuk lisan maka dimungkinkan adanya pengingkaran terhadapa apa yang sudah diperjanjikan., Dalam salah satu narasumber yang Penulis lakukan wawancara, biarpun perjanjian kerjanya dilakukan lisan tetapi hubungan kerja yang sudah terjadi. Berjalan dalam kurun waktu lebih dari 20 Tahun, artinya bahwa perjanjian kerja apapun bentuknya baik lisan maupun tertulis akan berjalan efektif dan bisa berfungsi sebagai hukum bagi para pihak yang membuatnya adalah tergantung komitmen dari para pihak, karena sesungguhnya apa yang diperjanjikan sudah disepakati sejak awal, seperti tentang upah yang diterima karyawan, jam dan hari kerja karyawan. Dari 3 orang narasumber yang penulis wawancarai, rata rata mempunyai masa kerja menjadi karyawan notaris, diatas 10 tahun di notaris yang sama. Jadi bisa ditarik kesimpulan bahwa meskipun perjanjian kerja dibuat secara lisan tapi dalam kenyataannya berjalan efektif.

Sedangkan menurut Hubungan Industrial Pancasila, hubungan kerja yang sesuai dengan Hubungan Indutrial Pancasila adalah hubungan antara para pelaku dalam proses produksi barang dan jasa yang didasarkan atas nilai-nilai luhur dari pancasila dan UUD 1945 yang merupakan pedoman hidup bangsa Indonesia. Konsep dalam Hubungan Industrial Pancasila yang mengatur antara para pelaku dan proses produksi yang 
berdasarkan nilai-nilai luhur dalam Pancasila, dengan adanya nilai-nilai Pancasila seperti sifat kebersamaan dan gotong royong yang merupakan sendi penting dalam Hubungan Industrial Pancasila. Hubungan Industrial Pancasila membuat pengusaha dan pekerja bukan lagi bersebrangan melainkan memiliki tujuan yang sama untuk mencapai keuntungan. Seiring berjalannya waktu kedudukan hubungan industrial Pancasila di Indonesia belum berjalan sesuai dengan harapan dan dianggap masih tidur, karena masih banyak permasalahan dalam hubungan indutstrial yang belum terselesaikan.Kedudukan Hubungan Industrial Pancasila di Indonesia pada zaman sekarang ini sudah mulai terlupakan, disebabkan karena beberapa hal, seperti:

1. Sikap mental dari para pihak dalam hubungan industrial.

2. Buruknya penegakan hukum dalam masalah ketenagakerjaan

3. Peraturan yang substansinya kurang baik

4. Budaya hukum masyarakat

Kedudukan Hubungan Industrial Pancasila harus di perhatikan oleh para pelaku hubungan industri agar hubungan industri di Indonesia bisa berjalan dengan baik.

Uraian diatas menjelaskan bahwa dalam hubungan kerja yang terjadi antara karyawan dan notaris hendaknya berpedoman kepada Pancasila, filosofi Pancasila sangatlah tepat diterapkan dalam Hubungan kerja tersebut, Perjanjian kerja jika dibuat oleh masing-masing pihak berdasarkan nilainilai Pancasila maka akan menghindari konflik yang terjadi antara karyawan dan notaris, berdasarkan penelitian yang dilakukan oleh penulis, meskipun perjanjian kerjanya dibuat secara lisan akan tetapi selama ini konflik yang terjadi bisa diselesaikan dengan musyawarah, hal ini dibuktikan dengan tidak adanya perselisihan antara karyawan dan notaris yang sampai ke pengadilan, jika terjadi konflik maka diselesaikan secara internal di dalam kantor notaris yang bersangkutan.

Aloysius Uwiyono memandang hubungan kerja dalam konteks hukum Indonesia adalah bahwa hubungan kerja berkaitan dengan hubungan kontraktual $^{8}$ yang dibuat antara pekerja dengan pengusaha.

Faktor lain yang mempengaruhi dasar hubungan kerja adalah berkembangnya model hubungan industrial yang dianut oleh negara yang bersangkutan. Dalam hal ini terdapat dua model hubungan industrial yaitu corporatist model dan contractualist model. Yang pertama suatu model hubungan kerja di mana peran Pemerintah sangat dominant dalam menentukan syarat-syarat kerja dan kondisi kerja (corporatist model) dan yang kedua model hubungan industrial di mana peran Pemerintah sangat

\footnotetext{
${ }^{8}$ Aloysius Uwiyono, "Dinamika Ketentuan Hukum tentang Pesangon," dalam http:// www.Hukumonline diakses pada tanggal 21 Desember 2018.
} 
minim atau rendah(contractualist model). Hubungan industrial yang lain menyebutkan peran serikat pekerja sangat besar (multi union system). ${ }^{9}$

Hubungan kerja didasarkan pada perjanjian kerja, perjanjian kerja bersama dan peraturan perusahaan. Hubungan hukum yang berdasarkan pada hubungan kontraktual sebenarnya telah dianut di Indonesia sejak berlakunya Burgelijk Wetboek $(\mathrm{BW})^{10}$ atau yang lazim sekarang disebut dengan Kitab Undang-undang Hukum Perdata. Berdasarkan prinsip kebebasan berkontrak ${ }^{11}$ dalam hukum perdata/hukum privat, dinyatakan bahwa siapapun yang memenuhi syarat berhak melakukan perjanjian dengan pihak lain dan perjanjian tersebut berlaku sebagai undang-undang bagi para pihak yang membuatnya.

Asas kebebasan berkontrak mempunyai hubungan erat dengan asas konsensualisme dan asas kekuatan mengikat yang terdapat dalam Pasal 1338 (Ayat 1) KUH Perdata. Asas kebebasan berkontrak (contravijheid) berhubungan dengan isi perjanjian yaitu kebebasan menentukan apa dan dengan siapa perjanjian itu diadakan.

Dari penjelasan diatas dan mengkaji hasil penelitian yang sudah penulis lakukan bahwa kebebasan berkontrak antara karyawan dan notaris, perjanjian kerja nya secara lisan hal ini memang sesuai dengan asas kebebasan kontrak yaitu para pihak menentukan sendiri bentuk kontrak tersebut.

Dalam pekembangannya hal ini memang berjalan efektif akan tetapi jika dilakukan secara lisan tidak memberikan perlindungan terhadap karyawan, meskipun demikian dari narasumber yang penulis wawancarai para Karyawan tersebut bisa bekerja di 1 Kantor notaris yang sama, selama lebih dari 5 tahun. Perjanjian kerja secara lisan memang diperbolehkan sepanjang sesuai dengan Peraturan Perundang-undangan di bidang ketenagakerjaan.

\section{KESIMPULAN}

Hubungan hukum yang terjadi antara notaris dan karyawan adalah hubungan kerja, dimana notaris sebagai pemberi kerja dan karyawan sebagai penerima kerja, Notaris meskipun bukan sebagai pengusaha, karena tanggung jawab dan pekerjaannya maka dia digolongkan sebagai penerima

\section{${ }^{9}$ Ibid.}

${ }^{10}$ Indonesia masih menggunakan dasar hukum dalam BW/KUH Perdata, khususnya juga mengenai masalah hukum perburuhan mulai dari pasal $1601 \mathrm{a}$ - pasal 1752 KUH Perdata.

${ }^{11}$ Sutan Remi Sjahdeini, Kebebasan Berkontrak dan Perlindungan Seimbang bagi Para Pihak dalam Perjanjian Kredit Bank di Indonesia, (Jakarta : Institut Bankir, 1993), hal. 105. 
kerja. Hal ini dikarenakan antara notaris dan karyawan terdapat adanya perintah/pekerjaan, upah, dan unsur waktu.

Dalam hubungan hukum antara karyawan dan notaris lahirlah apa yang dikenal sebagai perjanjian kerja secara lisan, hal ini menurut peraturan perundang-undangan diperbolehkan sepanjang dilakukan dalam hal pekerjaan yang bersifat tetap dan terus menerus seperti pekerjaan yang dilakukan oleh seorang notaris dan karyawan. Dari apa yang penulis teliti, terdapat fakta bahwa, notaris di Kota Malang Lazim menggunakan perjanjin kerja secara lisan. Meskipun perjanjian kerjanya dibuat secara lisan, tapi dalam faktanya ini berjalan efektif, Hal ini bisa dibuktikan dengan bahwa karyawan notaris yang tidak mempersoalkan jika tidak ada perjanjian kerja secara lisan. Meskipun banyak hak-hak karyawan yang merupakan kewajiban seorang notaris belum terpenuhi, tetapi hubungan kerja antara karyawan dan notaris terus terjadi sampai bisa puluhan tahun, bahkan sampai notaris yang bersangkutan sudah purna tugas.

\section{DAFTAR PUSTAKA}

\section{Buku}

Abdul Wahid, Mariyadi, dan Sunardi, 2017, Penegakan Kode Etik Notaris, Jakarta: Nirmana Media.

Bambang Waluyo ,2007, Penelitian Hukum dalam Praktek, Jakarta: Sinar Grafika.

R. Soeroso, 2005,Pengantar Ilmu Hukum, Jakarta, Sinar Grafika.

Sutan Remi Sjahdeini, 1993, Kebebasan Berkontrak dan Perlindungan Seimbang bagi Para Pihak dalam Perjanjian Kredit Bank di Indonesia, Jakarta: Institut Bankir.

Soedikno Mertokusumo, 2010, Mengenal Hukum suatu Pengantar, Yogyakarta: Liberty.

Soerjono,Soekanto. 1986. Pengantar Penelitian Hukum,Jakarta: UI Press. .2008.Faktor-faktor yang Mempengaruhi Penegakan Hukum, Jakarta: Raja Grafindo Persada.

\section{Peraturan Perundang-undangan}

Kitab Undang-undang Hukum Perdata

Undang-Undang Republik Indonesia Nomor 2 Tahun 2014 Tentang Jabatan Notaris

Undang Nomor Republik Indonesia Nomor 40 Tahun 2004 tentang Sistem Jaminan Sosial Nasional

Undang-Undang Republik Indonesia Nomor 24 Tahun 2011 tentang Badan Penyelenggara Jaminan Sosial 
EFEKTIVITAS PERJANJIAN KERJA ANTARA

KARYAWAN DENGAN NOTARIS (Pramadita Anggara Putra)

Undang-Undang Republik Indonesia Nomor 13 Tahun 2003 tentang Ketenagakerjaan

\section{Internet}

Aloysius Uwiyono, "Dinamika Ketentuan Hukum tentang Pesangon," dalam http:// www.Hukumonline diakses pada tanggal 21 Desember 2018. 